\title{
The Effects of Treatment on Hematological Parameters in the Patients with Acne Vulgaris
}

\author{
Akne Vulgaris Hastalarında Tedavinin Hematolojik Parametreler Üzerine \\ Etkisi
}

\author{
Ercan SARUHAN ${ }^{1}$, Emine Tuğba ALATAŞ ${ }^{2}$
}

${ }^{1}$ Muğla Sıtkı Koçman Üniversitesi, Tıp Fakültesi, Tıbbi Biyokimya Anabilim Dalı, Muğla

${ }^{2}$ Muğla Sitkı Koçman Üniversitesi, Tıp Fakültesi, Deri ve Zührevi Hastalıklar Anabilim Dalı, Muğla

\begin{abstract}
$\overline{\mathbf{O z}}$
Akne vulgaris pilosebase ünitenin multifaktöriyel inflamatuvar hastalığıdır. Akne vulgaris gelişiminde çeşitli immünolojik ve inflamatuar faktörler farklı patofizyolojik mekanizmalarla sebum üretimini artırarak rol oynamaktadır. Bu çalışmanın amacı, akne vulgaris tedavi öncesi ve sonrası hemogram parametrelerinde meydana gelen değişiklikleri ortaya koymak ve bu parametrelerin tedavinin değerlendirilmesinde etkinliğini araştırmaktır. Çalıșmaya 162 hasta (109 kadın, 67.3\%; 53 erkek, 32.7\%) dahil edildi. Çalışma sonucunda NEU, MPV, P-LCR ve PDW düzeylerinin tedavi sonrasında anlamlı derecede azaldığı saptandı $(\mathrm{p}<0.001)$. NLR ve PLR değerlerinde de tedavi sonrası anlamlı bir düşüş görüldü $(\mathrm{p}<0.001)$. LYM ve PLT sayısının ise tedavi sonrası arttı̆̆ görüldü $(\mathrm{p}<0.001)$. Akne vulgarisli hastalarda sistemik izotretinoin tedavisini değerlendirmede NLR, PLR ve PLCR gibi hemogram parametreleri etkin şekilde kullanılabilir.
\end{abstract}

Anahtar Kelimeler: Akne Vulgaris, İnflamasyon, Nötrofil/Lenfosit Oranı, Platelet

\section{Introduction}

Acne vulgaris is a multifactorial disease of the pilosebaceous unit (1). It is the most common skin disease affecting approximately $80 \%$ of the young population. Although it is primarily a disease of the adolescent period, it also occurs in the neonatal and infancy periods, prepubertal period, and adult patients (2,3). Various immunological and inflammatory factors play a role with different pathophysiological mechanisms in the development of acne vulgaris by increasing sebum production (4). Propionibacterium acnes colonize in the sebaceous follicle and cause an inflammatory papule, pustule, or nodule by increasing immune response (5). The sebocytes are effective on IL-1 and free fatty acids, and present antigen to $\mathrm{T}$ lymphocytes and activate them (6).

Isotretinoin is the most effective drug in the treatment of severe acne vulgaris (7). It is a retinoid derivative drug that reduces sebum production from

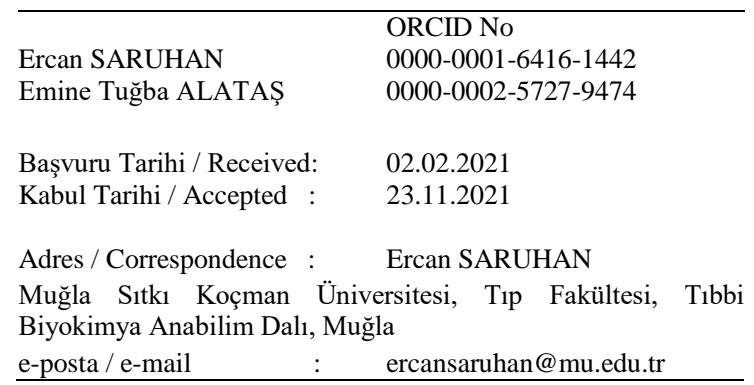

\begin{abstract}
Acne vulgaris is a multifactorial disease of the pilosebaceous unit. Various immunological and inflammatory factors play a role with different pathophysiological mechanisms in the development of acne vulgaris by increasing sebum production. The aim of this study was to reveal the changes in CBC sub-parameters and calculated parameters before and after acne vulgaris treatment and to enable these parameters to be used as non-invasive, low-cost, effective new laboratory tests in the evaluation of treatment efficacy. A total of 162 patients (109 females, 67.3\%; 53 males, 32.7\%) were included in this study. In this study, it was found that NEU, MPV, P-LCR, and PDW levels decreased significantly after treatment $(p<0.001)$. There was a significant decrease in NLR and PLR values $(\mathrm{p}<0.001)$. LYM and PLT count increased significantly after the treatment ( $\mathrm{p}<0.001)$. CBC parameters such as NLR, PLR, and P-LCR can be used to evaluate the efficacy of systemic isotretinoin treatment in patients with acne vulgaris.

Keywords: Acne Vulgaris, Inflammation, Neutrophil to Lymphocyte Ratio, Platelet
\end{abstract}

sebaceous glands, regulates follicular keratinization, prevents the development of microcomedones and comedones. In addition, it has an anti-inflammatory effect by decreasing the number of P.acnes (8).

Although routine inflammatory parameters such as procalcitonin, c-reactive protein (CRP), and erythrocyte sedimentation rate (ESR) are frequently used in the diagnosis and follow-up of systemic inflammatory diseases (9). Recently, new inflammatory parameters calculated from the complete blood count (CBC) parameters such as NLR have been used widely, because of its lower cost compared to other tests (10). The aim of this study was to reveal the changes in CBC parameters and calculate parameters before and after acne vulgaris treatment and to enable these parameters to be used as non-invasive, low-cost, effective new laboratory tests in the evaluation of treatment efficacy.

\section{Material and Method}

This retrospective observational study was conducted in Mugla Research and Training Hospital between 2018 and 2020. The inflammatory parameters of the patients with acne vulgaris were evaluated before and one month after isotretinoin treatment. We enrolled 214 participants who were referred to dermatology outpatient department. Patients were excluded if they had an acute inflammation, a history of liver, kidney, or 
hematologic disease, or were aged under 18 years. After exclusions remaining 162 patients were included in our study

CBC parameters such as white blood cells (WBC), neutrophil (NEU), lymphocyte (LYM), Platelet (PLT) count, Plateletcrit, mean platelet volume (MPV), platelet distribution width (PDW), and platelet larger cell ratio (P-LCR), red cell distribution width (RDW) of the patients were evaluated before and after the treatment. Blood samples collected into ethylene diamine tetraacetic acid (EDTA) were analyzed using a Sysmex XN1000 hematology analyzer (Sysmex, Kobe, Japan). All the data were collected from the hospital information system. Neutrophil to lymphocyte ratio (NLR) and platelet to lymphocyte ratio (PLR) were calculated by dividing neutrophil and platelet counts to lymphocyte counts, respectively.

This study was reviewed and approved by the Human Research Ethical Board of Muğla Sitk1 Koçman University (21/07/2020-156).

Statistical analysis was done using SPSS software (IBM SPSS Statistics, Version 22.0. Armonk, NY: IBM Corp). The Shapiro-Wilk test was used to determine whether the distribution of variables is normal. Variables with normal distribution were presented as mean \pm SD and nonnormally distributed variables were presented as median, and minimum, maximum. Differences among the groups for each parameter were analyzed by Wilcoxon Signed Ranks test. All p values less than 0.05 were considered statistically significant.

\section{Results}

A total of 162 patients (109 females, 67.3\%; 53 males, $32.7 \%$ ) were included in this study. The mean age of patients was $21.4 \pm 3.4$ (range 18-38 years). Post hoc power calculations were applied and the sample size was seen to provide 0.989 power and 0.649 effect size for lymphocyte count at $\alpha$ error probability level of 0.05 .

When the inflammatory parameters of the patients before and after the treatment were compared, it was found that NEU, MPV, P-LCR, and PDW levels decreased significantly after the treatment $(p<0.001$, Wilcoxon Signed Ranks test, Table 1). There was also a significant decrease in NLR and PLR values ( $\mathrm{p}<0.001$, Figure 1 and 2$)$. The NLR and PLR levels were $1.86 \pm 0.87$ and $122.7 \pm 38.4$ before treatment as were $1.69 \pm 0.90$ and $118.6 \pm 39.8$ after treatment, respectively. On the other hand, LYM, and PLT counts increased significantly after treatment $(p<0.001)$. No statistically significant difference was found in other parameters such as WBC, PCT, and RDW (p>0.05).
Table 1. Changes in hematological parameters before and after treatment

\begin{tabular}{|c|c|c|c|}
\hline & $\begin{array}{c}\text { Before } \\
\text { treatment }\end{array}$ & $\begin{array}{c}\text { After } \\
\text { treatment }\end{array}$ & p value \\
\hline $\mathrm{WBC}\left(10^{3} / \mu \mathrm{L}\right)$ & $\begin{array}{c}7.30 \\
(3.69-19.13)\end{array}$ & $\begin{array}{c}7.46 \\
(4.01-15.26)\end{array}$ & 0.646 \\
\hline Neutrophil $\left(10^{3} / \mu \mathrm{L}\right)$ & $\begin{array}{c}4.03 \\
(1.71-14.94)\end{array}$ & $\begin{array}{c}3.67 \\
(1.42-10.49)\end{array}$ & $<0.001$ \\
\hline Lymphocyte $\left(10^{3} / \mu \mathrm{L}\right)$ & $\begin{array}{c}2.39 \\
(1.12-4.24)\end{array}$ & $\begin{array}{c}2.83 \\
(1.34-4.75)\end{array}$ & $<0.001$ \\
\hline Platelet $\left(10^{3} / \mu \mathrm{L}\right)$ & $\begin{array}{c}271 \\
(152-446)\end{array}$ & $\begin{array}{c}280 \\
(137-477)\end{array}$ & 0.001 \\
\hline PCT $(\%)$ & $\begin{array}{c}0.29 \\
(0.15-0.45)\end{array}$ & $\begin{array}{c}0.29 \\
(0.13-0.47)\end{array}$ & 0.134 \\
\hline MPV (fL) & $\begin{array}{c}10.6 \\
(9.1-13.4)\end{array}$ & $\begin{array}{c}10.3 \\
(9.0-13.6)\end{array}$ & $<0.001$ \\
\hline P-LCR (\%) & $\begin{array}{c}30.0 \\
(15.1-58.2)\end{array}$ & $\begin{array}{c}29.1 \\
(14.8-55.4)\end{array}$ & $<0.001$ \\
\hline PDW (\%) & $\begin{array}{c}12.5 \\
(9.4-18.7)\end{array}$ & $\begin{array}{c}12.1 \\
(9.6-19.5)\end{array}$ & $<0.001$ \\
\hline RDW (\%) & $\begin{array}{c}39.3 \\
(34.7-51.4)\end{array}$ & $\begin{array}{c}39.5 \\
(32.7-51.0)\end{array}$ & 0.141 \\
\hline NLR & $\begin{array}{c}1.65 \\
(0.52-6.50)\end{array}$ & $\begin{array}{c}1.48 \\
(0.48-9.80)\end{array}$ & $<0.001$ \\
\hline PLR & $\begin{array}{c}115.9 \\
(47.0-264.7)\end{array}$ & $\begin{array}{c}112.3 \\
(34.3-291.7)\end{array}$ & $<0.001$ \\
\hline
\end{tabular}

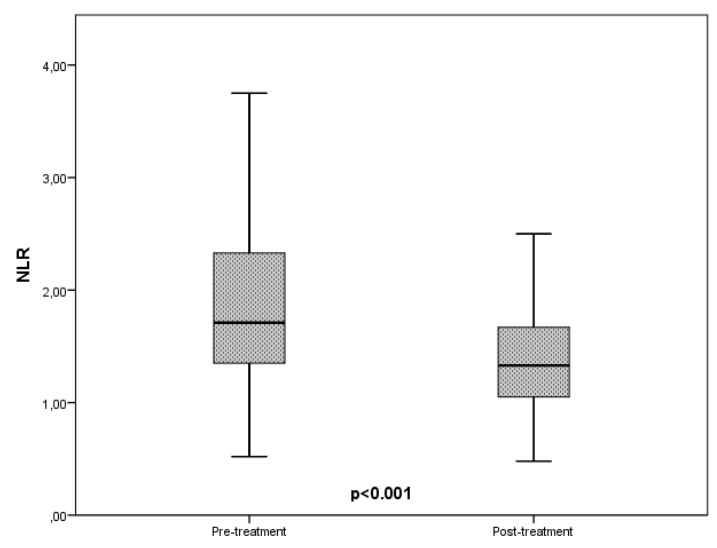

Figure 1. NLR levels before and after treatment

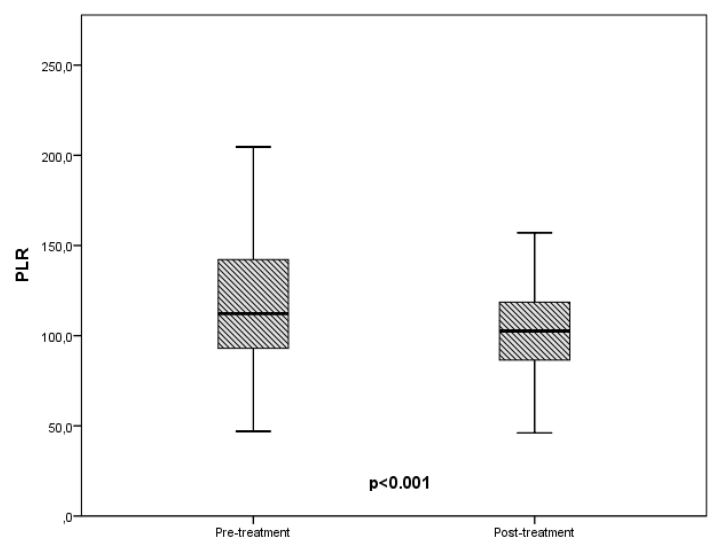

Figure 2. PLR levels before and after treatment

\section{Discussion}

Acne vulgaris is a chronic inflammatory disease of the pilosebaceous unit and affects approximately $80 \%$ of adolescents. According to the severity of the disease, acne vulgaris is treated with topical or systemic treatments (1). Isotretinoin, a synthetic retinoid, has been used for many years in the 
treatment of acne vulgaris. It induces apoptosis and inhibits proliferation in various cell types (11).

Currently, there is no biochemical marker to evaluate the activity of acne vulgaris. For this reason, objective, reliable laboratory parameters that can be used in acne vulgaris follow-up are investigated. Recently published studies have shown that the increase in systemic inflammatory markers in the patients with acne vulgaris indicates that this disease is associated with other systemic inflammatory diseases (12). The CBC is a widely used inexpensive and reliable laboratory test. Several parameters such as cytokines, interleukins, and adhesion molecules have been reported in the literature, which are complex, and expensive tests (13). Therefore, there is a need for inexpensive and simple parameters that can determine the inflammatory response in acne vulgaris. In this study, we compared CBC parameters in the patients with acne vulgaris before and after isotretinoin treatment.

CBC parameters have been studied in previous studies (14-18). Especially calculated parameters such as NLR and PLR may be good predictors to evaluate the efficacy of systemic treatment. Systemic inflammation triggers lymphopenia, causing an increase in NLR levels (19). In the current study, decreased NLR levels response to the treatment were in line with previous studies $(15,16,20)$. Previous studies have demonstrated different results on platelet values $(21,22)$. In this study, we found statistically significant changes in P-LCR, PLT, MPV, and PDW levels in the patients with acne vulgaris treated with isotretinoin.

The limitations of this study were retrospective design and lack of other inflammatory parameters such as sedimentation rate, procalcitonin, and CRP. There is a need for further prospective studies with larger samples and other inflammatory markers to fully elucidate the mechanisms of inflammatory response in acne vulgaris with long-term clinical outcomes.

In conclusion, the results of this study demonstrated that CBC parameters such as NLR, PLR, and P-LCR can be used to evaluate the efficacy of systemic isotretinoin treatment in the patients with acne vulgaris.

Ethics Committee Approval: This study was reviewed and approved by the Human Research Ethical Board of Muğla Sitkı Koçman University (21/07/2020-156).

\section{References}

1. Williams HC, Dellavalle RP, Garner S. Acne vulgaris. Lancet. 2012;379(9813):361-72.
2. Rapp DA, Brenes GA, Feldman SR, et al. Anger and acne: implications for quality of life, patient satisfaction and clinical care. Br J Dermatol. 2004;151(1):183-9.

3. Tom WL, Friedlander SF. Acne through the ages: case-based observations through childhood and adolescence. Clin Pediatr (Phila). 2008;47(7):639-51.

4. Tanghetti EA. The role of inflammation in the pathology of acne. J Clin Aesthet Dermatol. 2013;6(9):27-35.

5. Gollnick H, Cunliffe W, Berson D, et al. Management of acne: a report from a Global Alliance to Improve Outcomes in Acne. J Am Acad Dermatol. 2003;49(1):1-37.

6. Oeff MK, Seltmann H, Hiroi N, et al. Differential Regulation of Toll-Like Receptor and CD14 Pathways by Retinoids and Corticosteroids in Human Sebocytes. Dermatology. 2006;213(3):266.

7. Zaenglein AL, Pathy AL, Schlosser BJ, et al. Guidelines of care for the management of acne vulgaris. J Am Acad Dermatol. 2016;74(5):945-73.

8. Oge LK, Broussard A, Marshall MD. Acne Vulgaris: Diagnosis and Treatment. Am Fam Physician. 2019;100(8):475-84.

9. Bray C, Bell LN, Liang H, et al. Erythrocyte Sedimentation Rate and C-reactive Protein Measurements and Their Relevance in Clinical Medicine. Wmj. 2016;115(6):317-21.

10. Cataudella E, Giraffa CM, Di Marca S, et al. Neutrophil-ToLymphocyte Ratio: An Emerging Marker Predicting Prognosis in Elderly Adults with Community-Acquired Pneumonia. J Am Geriatr Soc. 2017;65(8):1796-801.

11. Katsambas A, Papakonstantinou A. Acne: Systemic treatment. Clin Dermatol. 2004;22(5):412-8.

12. Imtiaz F, Shafique K, Mirza SS, et al. Neutrophil lymphocyte ratio as a measure of systemic inflammation in prevalent chronic diseases in Asian population. Int Arch Med. 2012;5(1):2-6.

13. Abd-Elmaged WM, Nada EA, Hassan MH, et al. Lesional and circulating levels of interleukin-17 and 25hydroxycholecalciferol in active acne vulgaris: Correlation to disease severity. J Cosmet Dermatol. 2019;18(2):671-6.

14. Gencoglan G, Inanir I, Miskioglu M, et al. Evaluation of sequential effect of isotretinoin on the haematological parameters in patients with acne vulgaris. Cutan Ocul Toxicol. 2018;37(2):139-42.

15. Turkmen D, Altunisik N, Sener S. Investigation of monocyte HDL ratio as an indicator of inflammation and complete blood count parameters in patients with acne vulgaris. Int J Clin Pract. 2020;74(12):e13639.

16. Seçkin HY, Baş Y, Takçı Z, et al. Effects of isotretinoin on the inflammatory markers and the platelet counts in patients with acne vulgaris. Cutan Ocul Toxicol. 2016;35(2):89-91.

17. Önder S, Ozturk M. Can monocyte/HDL show inflammatory activity of isotretinoin treatment in acne patients? Cutan Ocul Toxicol. 2020;39(2):111-4

18. Kutlu Ö. Effect of isotretinoin treatment on the inflammatory markers in patients with acne vulgaris: can monocyte/HDL be a new indicator for inflammatory activity of isotretinoin treatment? Cutan Ocul Toxicol. 2020;39(1):67-70.

19. Milner JD, Ward JM, Keane-Myers A, et al. Lymphopenic mice reconstituted with limited repertoire $\mathrm{T}$ cells develop severe, multiorgan, Th2-associated inflammatory disease. Proceedings of the National Academy of Sciences. 2007;104(2):576-81.

20. Metin N, Turan Ç. Increases in uric acid and monocyte-highdensity lipoprotein ratio as possible atherosclerotic indicators in acne patients using isotretinoin. J Cosmet Dermatol. 2021.

21. Jansen T, Altmeyer P. Thrombocytosis induced by low-dose isotretinoin. Int J Dermatol. 2000;39(12):956-7.

22. Moeller KE, Touma SC. Prolonged Thrombocytopenia Associated with Isotretinoin. Annals of Pharmacotherapy. 2003;37(11):1622-4 